\title{
Quantitative analysis of penicillins in porcine tissues, milk and animal feed using derivatisation with piperidine and stable isotope dilution liquid chromatography tandem mass spectrometry
}

\author{
Frédérique van Holthoon • Patrick P. J. Mulder • \\ Eric O. van Bennekom • Henri Heskamp • \\ Tina Zuidema • Hans (J.) A. van Rhijn
}

Received: 16 November 2009 /Revised: 26 January 2010 / Accepted: 1 February 2010 /Published online: 26 February 2010

(C) The Author(s) 2010. This article is published with open access at Springerlink.com

\begin{abstract}
Penicillins are used universally in both human and veterinary medicine. The European Union (EU) has established maximum residue levels (MRLs) for most $\beta$ lactam antibiotics in milk and animal tissues and included them in the National Residue Monitoring Programs. In this study, a novel method is described for the determination and confirmation of eight penicillins in porcine tissues, milk and animal feed by liquid chromatography-tandem mass spectrometry (LC-MS/MS). To prevent degradation of penicillin residues during workup, a derivatisation procedure was developed, by which penicillins were converted to stable piperidine derivatives. Deuterated piperidine derivatives were synthesised for all relevant penicillins, enabling the use of isotope dilution for accurate quantification. Penicillin residues were derivatised in the crude extract with piperidine and isolated using solid-phase extraction. The penicillin piperidine derivatives were determined by LC-MS/MS. The method was validated at the current MRLs, which range from $25-300 \mu \mathrm{g} \mathrm{kg}^{-1}$ in muscle and kidney to $4-30 \mu \mathrm{g} \mathrm{kg}^{-1}$ in milk as well as at the target value of $100 \mu \mathrm{g} \mathrm{kg}^{-1}$ chosen for animal feed, according to the EU requirements for a quantitative confirmatory
\end{abstract}

F. van Holthoon • P. P. J. Mulder $(\bowtie) \cdot$ E. O. van Bennekom •

H. Heskamp · T. Zuidema

RIKILT - Institute of Food Safety, Wageningen UR,

Akkermaalsbos 2, P.O. Box 230, 6700 AE Wageningen,

The Netherlands

e-mail: patrick.mulder@wur.nl

H. (J.) A. van Rhijn

Food and Consumer Product Safety Authority

(VWA) - Lab Region East,

P.O. Box 19506, 2500 CM Den Haag, The Netherlands method. Accuracy ranged from 94-113\% (muscle), $83-$ $111 \%$ (kidney) and $87-103 \%$ (milk) to $88-116 \%$ (animal feed). Intra-day precision (relative standard deviation $(\mathrm{RSD})_{\mathrm{r}}$ ) ranged from 5-13\% (muscle, $n=18$ ), 4-17\% (kidney, $n=7$ ) and $5-18 \%$ (milk, $n=7$ ) to $11-32 \%$ (animal feed, $n=18$ ). Inter-day precision $\left(\mathrm{RSD}_{\mathrm{RL}}, n=18\right)$ ranged from $6-23 \%$ (muscle) to $11-36 \%$ (animal feed). From the results, it was concluded that the method was fit for purpose at the target MRLs in animal tissue and target levels for animal feed.

Keywords Penicillins · Piperidine $\cdot$ Derivatisation LC-MS/MS · Isotope dilution · Validation

\section{Introduction}

The introduction of penicillin to treat bacterial infections has been one of the most important lifesaving medical discoveries of the twentieth century. Today, penicillins are still universally used both in human and veterinary medicine. Unfortunately, indiscriminate use of penicillins and other B-lactam antibiotics has been blamed for the increase of bacterial resistance to antibiotics. Furthermore, the consumption of food products containing penicillin drug residues may be harmful to allergic consumers [1-3]. Therefore, the European Union (EU) has established maximum residue levels (MRLs) for most B-lactam antibiotics (Fig. 1) in milk and animal tissues (see Table 1) and included them in National Residue Monitoring Programs [4]. Penicillins can be administered to livestock in a number of ways (e.g. in feed, water), but only amoxicillin (AMX) has actually been registered both as a feed and water 
Fig. 1 Structures of penicillins, derivatised penicillins and derivatised internal standards<smiles>[R]C(=O)[C@H](N)c1ccc(O)cc1</smiles>

AMX<smiles>[R]C(=O)Cc1ccccc1</smiles>

PNG<smiles>[R]C(=O)c1c(-c2ccccc2)noc1C</smiles>

OXA<smiles>CCC(=O)c1c(-c2c(Cl)cccc2Cl)noc1C</smiles>

DIC<smiles>[R]C(=O)[C@H](N)c1ccccc1</smiles><smiles>CCC(=O)COc1ccccc1</smiles>
PNV<smiles>CCC(=O)c1c(-c2ccccc2Cl)noc1C</smiles>

CLO<smiles>[R]C(=O)c1c(OCC)ccc2ccccc12</smiles>

NAF<smiles>[R]N[C@H]1C(=O)N2[C@@H](C(=O)O)C(C)(C)S[C@H]12</smiles>

Penicillin structure<smiles>[R]N[C@H](C(=O)N1CCCCC1)[C@@H]1N[C@H](C(=O)O)C(C)(C)S1</smiles>

Penicillin- $d_{0}$-piperidine<smiles>[R]N[C@H](C(=O)N1CCCCC1)[C@@H]1N[C@H](C(=O)O)C(C)(C)S1</smiles>

Penicillin- $d_{10}$-piperidine additive (premix 250-500 mg kg-1 ). Medication in feed is often preferred due to the low stability of penicillins in aqueous solutions [5]. Analysis and control of antibiotics in feedstuffs have become an important issue as feedstuffs can only be prepared under specific conditions as stated in Council Directive 90/167/EEC [6].

Over the years, many methods have been described for the analysis of penicillins in various matrices including animal feeds. Unfortunately, ß-lactams are known for their rapid degradation during sample preparation. The use of organic solvents and acids in extraction and chromatography has been implicated in the degradation of penicillins [7-9]. Losses may also occur during storage (milk [10], meat [11] and feed [5]). To stabilise penicillins during sample processing, several analytical methods apply derivatisation (benzoic anhydride with 1,2,4-triazole mercury (II) reagent [12-14] or formaldehyde with trichloroacetic acid [5]). An additional aim of derivatisation is the introduction of chemical moieties that improve detection by liquid chromatography-ultraviolet or fluorescence $[5,12]$.

Table 1 MRLs and target values for penicillin residues in animal tissue, milk and feed

\begin{tabular}{|c|c|c|c|c|}
\hline \multirow[t]{2}{*}{ Penicillin } & \multirow[t]{2}{*}{ Abbreviation } & \multicolumn{2}{|l|}{ MRL } & \multirow{2}{*}{$\begin{array}{l}\text { Target value } \\
\text { Animal feed }\left(\mu \mathrm{gkg}^{-1}\right)\end{array}$} \\
\hline & & $\operatorname{Tissue}^{\mathrm{a}}\left(\mu \mathrm{gkg}^{-1}\right)$ & $\operatorname{Milk}\left(\mu \mathrm{gkg}^{-1}\right)$ & \\
\hline Amoxicillin & AMX & 50 & 4 & 100 \\
\hline Ampicillin & AMP & 50 & 4 & 100 \\
\hline Penicillin G (benzylpenicillin) & PNG & 50 & 4 & 100 \\
\hline Penicillin V (phenoxymethylpenicillin) & PNV & $25^{\mathrm{bc}}$ & $4^{\mathrm{d}}$ & 100 \\
\hline Oxacillin & OXA & 300 & 30 & 100 \\
\hline Cloxacillin & CLO & 300 & 30 & 100 \\
\hline Dicloxacillin & DIC & 300 & 30 & 100 \\
\hline Nafcillin & NAF & 300 & 30 & 100 \\
\hline
\end{tabular}

${ }^{\text {a }}$ Muscle, liver, kidney

${ }^{\mathrm{b}}$ Poultry

${ }^{\mathrm{c}}$ Porcine

${ }^{\mathrm{d}}$ Target value 
Nowadays, liquid chromatography-tandem mass spectrometry (LC-MS/MS)-based methods for the determination of penicillins are widely available [15]. The reproducibility of quantitative LC-MS/MS methods is often improved when isotopically labelled internal standards can be incorporated. However, the introduction of isotopically labelled analogues of the penicillins is hampered by their complex structure. The only suitable penicillin internal standards described thus far are benzylpenicllin- ${ }^{13} \mathrm{C}_{2}[16]$, benzylpenicillin- $\mathrm{d}_{7}[7,17]$, benzylpenicillin- $\mathrm{d}_{5}$, ampicillin (AMP) $-\mathrm{d}_{6}$ and nafcillin (NAF) $-\mathrm{d}_{6}$ [18]. Alternatively, several methods describe the use of one of the other penicillins as IS [5, 19-23]. The use of other (nondeuterated) penicillins as internal standards is not advisable as these also have veterinary uses and they may exhibit different behaviours during extraction and chromatography as well. So far, no methods have been described that combine derivatisation of penicillins with LC-MS/MS. In this study, the use of piperidine (PIP) to stabilise penicillin residues in matrix by the formation of penicillin-piperidine derivatives is presented. Deuterated piperidine derivatives have been synthesised for all relevant penicillins, enabling the use of isotope dilution for the analysis of penicillins. The development and validation, according to EU guidelines of Commission Decision 2002/657/EC [24], in porcine muscle and kidney tissue as well as in milk and at low carryover levels in feedstuffs is described.

At RIKILT - Institute of Food Safety, feed and porcine tissue samples are screened with an in-house developed microbiological method [25]. Samples suspected to contain B-lactams are subsequently analysed using the confirmatory and quantitative method described in this paper. The method for animal tissues and milk has been in use for over 5 years and the method for feed for over 3 years.

\section{Experimental}

\section{Chemicals and reagents}

All chemicals and solvents were at least of analytical reagent grade and were purchased from local commercial suppliers. Acetic acid, ammonium acetate $\left(\mathrm{NH}_{4} \mathrm{Ac}\right)$, phosphoric acid $(85 \%)$, disodium hydrogen phosphate dibasic salt $\left(\mathrm{Na}_{2} \mathrm{HPO}_{4} \cdot 2 \mathrm{H}_{2} \mathrm{O}\right)$ and formic acid (FA, 98-100\%) were obtained from Merck (Darmstadt, Germany). Methanol $(\mathrm{MeOH})$ and acetonitrile $(\mathrm{MeCN})$ were supplied by Biosolve (Valkenswaard, the Netherlands), and piperidine was purchased from Fluka (Zwijndrecht, the Netherlands). Piperidine- $\mathrm{d}_{11}$ was obtained from CDN Isotopes (PointeClaire, Quebec, Canada). Amoxicillin, ampicillin, penicillin $\mathrm{G}$ (PNG), penicillin V (PNV), oxacillin (OXA), cloxacillin (CLO), dicloxacillin (DIC) and nafcillin were supplied by
Sigma-Aldrich (Zwijndrecht, the Netherlands). LC quality water (conductivity at least $10 \mathrm{M} \Omega \mathrm{cm}^{-1}$ ) was prepared with a Milli-Q water purification system (Millipore, St. Louis, MO, USA).

\section{Synthesis of penicillin-piperidine derivatives}

Derivatised penicillins were prepared by adding a piperidine solution in water $(1.00 \mathrm{ml}, 200 \mathrm{mM})$ to the solid penicillin base $(0.020 \mathrm{mmol})$. The mixture was shaken gently until the penicillin was completely dissolved. The reaction was allowed to proceed for $30 \mathrm{~min}$ at room temperature, whereupon acetic acid $(0.18 \mathrm{ml}, 1 \mathrm{M})$ was added. Finally, $\mathrm{NH}_{4} \mathrm{Ac}$ buffer (100 mM, pH 6.0) was added to obtain a stock solution with a concentration of $1 \mathrm{mg} \mathrm{ml}^{-1}$ of penicillin base equivalent. The corresponding deuterated analogues were obtained by using a piperidine- $\mathrm{d}_{10}$ solution in water. The derivatised penicillins were stable for 1 year when kept at $-20{ }^{\circ} \mathrm{C}$. The purity of the piperidine derivatives was assessed with LC-MS/MS and ${ }^{1} \mathrm{H}$-nuclear magnetic resonance (NMR) and found to be higher than $90 \%$. No non-derivatised starting material could be detected in the synthesised standards $(<1 \%)$.

\section{Standard solutions}

Stock standard solutions $\left(1 \mathrm{mg} \mathrm{ml}{ }^{-1}\right)$ of penicillin references were prepared in $\mathrm{MeOH}$, taking into account the purity of the reference standard material. The stock solutions were stable for 1 week when stored at $4-8{ }^{\circ} \mathrm{C}$.

From the stocks mixed, penicillin working standard solutions (PWS) were prepared. The concentrations of the individual penicillins were chosen to match the specific MRL in muscle and kidney tissue and in milk. For the analysis in tissue samples, a mixed penicillin working solution (PWS-tissue) was prepared by adding $100 \mu \mathrm{l}$ of stock solution of AMX, ampicillin (AMP) and PNG; $50 \mu \mathrm{l}$ of PNV stock; and $600 \mu \mathrm{l}$ of OXA, CLO, DIC and NAF stock solution to a 100-ml volumetric flask and making up to the mark with water. For milk samples, a mixed working solution (PWS-milk) was prepared by adding $16 \mu \mathrm{l}$ of AMX, AMP, PNG and PNV stock solution and $120 \mu \mathrm{l}$ of OXA, CLO, DIC and NAF stock solution to a $100-\mathrm{ml}$ volumetric flask and making up to the mark with water. For feed samples, a mixed working standard (PWS-feed) was prepared by adding $200 \mu \mathrm{l}$ of all penicillin stock solutions to a 100-ml volumetric flask and making up to the mark with water. PWS were stable for 1 week when stored at $4-8{ }^{\circ} \mathrm{C}$.

Mixed working standard solutions of penicillin- $\mathrm{d}_{0^{-}}$ piperidine derivatives (PPWS) and mixed internal standard solutions of the penicillin- $\mathrm{d}_{10}$-piperidine derivatives (PPIS) were prepared from the synthesised standards, matching the specific MRL levels in muscle and kidney tissue and in 
milk and were mixed in the same proportions as described for the penicillin working solutions. The PPWS and PPIS were stable for 1 month when stored at $4-8{ }^{\circ} \mathrm{C}$.

Working standards for tissue, milk and feed containing mixtures of the penicillin- $\mathrm{d}_{0}$-piperidines and penicillin- $\mathrm{d}_{10^{-}}$ piperidines were prepared by adding $250 \mu \mathrm{l}$ of the specific PPWS and $250 \mu \mathrm{l}$ of the corresponding PPIS in a $10-\mathrm{ml}$ volumetric flask and making up to the mark with water. These working standards were used to check the performance of the LC-MS/MS system.

Instrumentation

An Agilent 1100 Series high-performance liquid chromatography (HPLC) system (Agilent Technologies, USA) coupled to a Quattro Ultima ${ }^{\circledR}$ tandem mass detector (Waters-Micromass, Manchester, UK), both operating under MassLynx ${ }^{\circledR}$ software, was used for sample analysis. The mass spectrometer was operated in electrospray negative mode, and data acquisition was in multiple reaction monitoring mode (MRM). The precursor/product ions monitored are listed in Table 2. The source settings were as follows: capillary voltage $2.6 \mathrm{kV}$, source temperature $120^{\circ} \mathrm{C}$, desolvation temperature $300{ }^{\circ} \mathrm{C}$, cone voltage $30 \mathrm{~V}$, cone nitrogen gas flow $180 \mathrm{l} \mathrm{h}^{-1}$, desolvation gas flow $5801 \mathrm{~h}^{-1}$. Argon $\left(2.2 \times 10^{-3} \mathrm{mbar}\right)$ was used as the collision gas, and the multiplier was operated at $750 \mathrm{~V}$. The collision energy $(17-23 \mathrm{eV})$ was optimised for each analyte and each MRM (Table 2). The HPLC system was equipped with a $3.0 \times 150 \mathrm{~mm}, 5 \mu \mathrm{m}$ Symmetry $\mathrm{C}_{18}$ column (Waters, Milford, PA, USA) kept at $40{ }^{\circ} \mathrm{C}$. A binary gradient mobile phase was used at a flow rate of $0.4 \mathrm{ml} \mathrm{min}^{-1}$ with solvent A $(0.2 \% \mathrm{FA}$ in water $)$ and solvent $\mathrm{B}(0.2 \% \mathrm{FA}$ in $\mathrm{MeCN} /$ water $9 / 1(v / v))$. A splitter was used to reduce the solvent flow to $0.15 \mathrm{ml} \mathrm{min}^{-1}$ entering the mass spectrometer. The gradient started isocratically for $1 \mathrm{~min}$ at $15 \% \mathrm{~B}$, followed by a linear increase to $50 \% \mathrm{~B}$ in $7 \mathrm{~min}$, followed by a linear increase to $70 \% \mathrm{~B}$ in $5 \mathrm{~min}$. After an isocratic hold at $70 \%$ $\mathrm{B}$ for $1 \mathrm{~min}$, the gradient returned to $15 \% \mathrm{~B}$ in $1 \mathrm{~min}$ for equilibration of the column. Total run time was $20 \mathrm{~min}$. Sample injection volume was $50 \mu 1$.

${ }^{1} \mathrm{H}-\mathrm{NMR}$ spectra were recorded on a Bruker Avance $400 \mathrm{MHz}$ spectrometer. Presaturation was performed on the residual HDO resonance. A $90^{\circ}$ pulse was used; the total relaxation delay was $3.7 \mathrm{~s}$; the spectral width was $5,000 \mathrm{~Hz}$. The data were acquired in $16 \mathrm{~K}$ data points. Before Fourier transformation and phasing, a one-third-shifted sine squared window multiplication was applied and a zero filling to $128 \mathrm{~K}$ data points was applied. Calibration of spectra was achieved by setting the $\mathrm{HCD}_{2}$ resonance of deuterated methanol to $3.27 \mathrm{ppm}$.

Sample preparation: porcine muscle and kidney tissue

Porcine kidney and muscle tissue samples $(2 \mathrm{~g})$ were minced and homogenised with phosphate buffer $(2 \mathrm{ml}$, $200 \mathrm{mM}, \mathrm{pH}=6.0$ ). Internal standard mixture (PPIS-tissue, $100 \mu \mathrm{L}$ ) was added to all samples. After an incubation time of $30 \mathrm{~min}$ at room temperature, phosphate buffer $(100 \mathrm{mM}$, $\mathrm{pH}=8.0,40 \mathrm{ml})$ was added. The tubes were vortexed for $30 \mathrm{~s}$, followed by addition of piperidine $(300 \mu \mathrm{l})$. The tubes were vortexed for $30 \mathrm{~s}$, and the $\mathrm{pH}$ was checked with a $\mathrm{pH}$

Table 2 LC-MS/MS precursor/product ion combinations (quantifier italicised) monitored in ESI negative mode

\begin{tabular}{|c|c|c|c|c|c|}
\hline Penicillin & Derivatised penicillin & Internal standard & Precursor ion $(\mathrm{m} / \mathrm{z})$ & Product ions $(\mathrm{m} / \mathrm{z})$ & Collision energy $(\mathrm{eV})$ \\
\hline \multirow[t]{2}{*}{ AMX } & AMX-d ${ }_{0}$-PIP & & 449.2 & $277.2,371.2$ & 20 \\
\hline & & AMX-d ${ }_{10}$-PIP & 459.3 & 381.3 & 18 \\
\hline \multirow[t]{2}{*}{ AMP } & AMP-d ${ }_{0}$-PIP & & 433.2 & $270.2,355.2$ & 20 \\
\hline & & AMP-d ${ }_{10}$-PIP & 443.3 & 365.3 & 20 \\
\hline \multirow[t]{2}{*}{ PNG } & PNG-d $\mathrm{d}_{0}$-PIP & & 418.2 & $222.2,340.2$ & 20 \\
\hline & & PNG-d ${ }_{10}$-PIP & 428.3 & 350.3 & 20 \\
\hline \multirow[t]{2}{*}{ PNV } & PNV-d $\mathrm{d}_{0}-\mathrm{PIP}$ & & 434.2 & $262.2,356.2$ & 22 \\
\hline & & PNV-d ${ }_{10}-\mathrm{PIP}$ & 444.3 & 366.3 & 22 \\
\hline \multirow[t]{2}{*}{ OXA } & OXA- $\mathrm{d}_{0}-\mathrm{PIP}$ & & 485.2 & $322.2,407.2$ & 23 \\
\hline & & OXA-d ${ }_{10}-\mathrm{PIP}$ & 495.3 & 417.3 & 20 \\
\hline \multirow[t]{2}{*}{ CLO } & CLO-d ${ }_{0}-\mathrm{PIP}$ & & 519.2 & $405.2,441.2$ & 20 \\
\hline & & CLO-d ${ }_{10}-\mathrm{PIP}$ & 529.3 & 451.3 & 18 \\
\hline \multirow[t]{2}{*}{ DIC } & DIC- $\mathrm{d}_{0}-\mathrm{PIP}$ & & 553.2 & $439.2,475.2$ & 17 \\
\hline & & DIC-d ${ }_{10}$-PIP & 563.3 & 485.3 & 17 \\
\hline \multirow[t]{2}{*}{ NAF } & NAF-d $d_{0}-\mathrm{PIP}$ & & 498.2 & $263.2,420.2$ & 18 \\
\hline & & NAF-d ${ }_{10}-\mathrm{PIP}$ & 508.3 & 430.3 & 18 \\
\hline
\end{tabular}


stick and if necessary adjusted to 11-12 with piperidine. After agitation for $5 \mathrm{~min}$ on a rotary tumbler, phosphoric acid $(100 \mu \mathrm{l})$ was added and the samples were vortexed; the $\mathrm{pH}$ was adjusted to $8.0 \pm 0.5$ with phosphoric acid if necessary. Next, the samples were heated in a water bath at $85{ }^{\circ} \mathrm{C}$. After $5 \mathrm{~min}$, the samples were quickly cooled to room temperature by using an ice bath. The samples were centrifuged at $2,700 \times g$ for $10 \mathrm{~min}$, and the supernatants were filtered through a wad of cotton wool into polypropylene tubes. Cloudy extracts were centrifuged at $15,000 \times \mathrm{g}$ for $15 \mathrm{~min}$. Oasis ${ }^{\circledR}$ HLB $\left(60-\mathrm{mg}, 3-\mathrm{cm}^{3}\right.$ solid-phase extraction (SPE) cartridges, Waters, Manchester, UK) was conditioned using $2 \mathrm{ml}$ of $\mathrm{MeOH}, 2 \mathrm{ml}$ of water and $2 \mathrm{ml}$ phosphate buffer $(100 \mathrm{mM}, \mathrm{pH}=8.0)$. The cartridges were loaded with extract $(10 \mathrm{ml})$ and subsequently washed with $2 \times 2 \mathrm{ml}$ of water. After drying under reduced pressure, cartridges were eluted with $3 \mathrm{ml} \mathrm{MeOH} /$ water $(80 / 20, v / v)$. The eluate was evaporated to dryness at $60{ }^{\circ} \mathrm{C}$ under a stream of nitrogen and redissolved in $500 \mu 12 \% \mathrm{MeCN}$.

\section{Sample preparation: milk}

For the analysis of raw bovine milk, the porcine tissue method was used with a few adjustments. To the milk samples (4 g), internal standard mixture (PPIS-milk, $100 \mu \mathrm{l})$ was added. Phosphate buffer $(100 \mathrm{mM}, \mathrm{pH}=8.0$, $40 \mathrm{ml}$ ) was added, and the tubes were vortexed for $30 \mathrm{~s}$. Piperidine $(300 \mu \mathrm{l})$ was added, and after vortex agitation for $30 \mathrm{~s}$, the $\mathrm{pH}$ was checked with a $\mathrm{pH}$ stick and if necessary adjusted to 11-12 with piperidine. After agitation for $5 \mathrm{~min}$ on a rotary tumbler, phosphoric acid $(100 \mu \mathrm{l})$ was added and the samples were vortexed; the $\mathrm{pH}$ was adjusted to 8.0 \pm 0.5 with phosphoric acid if necessary. The samples were centrifuged at $2,700 \times g$ for $10 \mathrm{~min}$, and the supernatants were filtered through a wad of cotton wool into polypropylene tubes. SPE cartridges were loaded with $20 \mathrm{ml}$ of extract, and the final residue was reconstituted in $200 \mu \mathrm{l}$ of $2 \% \mathrm{MeCN}$.

\section{Sample preparation: animal feed}

Feeding stuffs were ground to a particle size of $0.5 \mathrm{~mm}$. To the feed samples $(2 \mathrm{~g})$, internal standard mixture (PPISfeed, $200 \mu \mathrm{l}$ ) was added. After an incubation time of $30 \mathrm{~min}$ at room temperature, phosphate buffer was added $(100 \mathrm{mM}$, $\mathrm{pH}=8.0,40 \mathrm{ml})$. The tubes were agitated for $15 \mathrm{~min}$ on a rotary tumbler. The samples were centrifuged for $10 \mathrm{~min}$ at $2,700 \times g$, and with a pipette $10 \mathrm{ml}$ of the supernatant was transferred to a $14 \mathrm{ml}$ polypropylene tube. Piperidine (300 $\mu 1)$ was added, and the samples were vortexed immediately. After agitation, the $\mathrm{pH}$ was checked and if necessary adjusted with piperidine to 11-12. After $5 \mathrm{~min}$, extracts were adjusted to $\mathrm{pH} 8.0 \pm 0.5$ with phosphoric acid
$(100-200 \mu 1)$. Subsequent purification with Oasis ${ }^{\circledR}$ HLB followed the procedure described for porcine tissue. After evaporation, the residue was reconstituted in $500 \mu 1$ of water/MeCN/FA $(98 / 2 / 0.2, v / v / v)$.

For accurate quantification, feed samples were analysed using a multi-level standard addition approach. The chosen addition levels depend on the concentrations expected in the feed. In case suspect samples (based on the in-house microbiological screening assay) were analysed, the indicative values derived from the screening assay were used to determine standard addition levels. Depending on the expected concentration, six standard addition levels were chosen and spiked accordingly. To samples suspected to contain more than $5 \mathrm{mg} \mathrm{kg}^{-1}$, a larger volume of PPIS mixture $(2 \mathrm{ml})$ was added. Depending on the results from the microbiological screening, an aliquot of the crude extract was taken and diluted with phosphate buffer $(100 \mathrm{mM}, \mathrm{pH}=8.0)$. Samples containing less than $1 \mathrm{mg} \mathrm{kg}^{-1}$ were not diluted, whereas samples suspected to contain between 1 and $5 \mathrm{mg} \mathrm{kg}^{-1}$ were diluted five times with phosphate buffer and samples containing between 5 and $50 \mathrm{mg} \mathrm{kg}^{-1}$ were diluted 50 times before derivatisation.

Quality control samples and matrix-matched standard preparation

For tissue and milk samples, calibration was performed using matrix-matched standards (MMS) prepared by adding the appropriate amounts of the penicillin mixed standard solution to blank matrix. For porcine tissue, MMS were prepared corresponding to $0 \mathrm{MRL}, 0.25 \mathrm{MRL}$ ( $25 \mu \mathrm{l}$ of PWS-tissue), 0.5 MRL $(50 \mu \mathrm{l})$, one MRL $(100 \mu \mathrm{l})$, two MRL $(200 \mu \mathrm{l})$ and five MRL $(500 \mu \mathrm{l})$. Internal standard mixture (PPIS-tissue, $100 \mu \mathrm{l}$ ) was added to all samples. For milk, MMS were prepared corresponding to $0 \mathrm{MRL}, 0.25$ MRL $(25 \mu$ l of PWS-milk), 0.5 MRL $(50 \mu \mathrm{l})$, one MRL $(100 \mu \mathrm{l})$, two MRL $(200 \mu \mathrm{l})$ and five MRL $(500 \mu \mathrm{L})$. Internal standard mixture (PPIS-milk, $100 \mu \mathrm{l}$ ) was added to all samples. Two blank samples spiked with IS were included in each series for the preparation of matrixmatched recovery standards. Penicillin- $\mathrm{d}_{0}$-piperidine mixed standard solution (PPWS-tissue) was added to the dried extracts to obtain concentrations corresponding to $0.5 \mathrm{MRL}$ $(12.5 \mu \mathrm{L})$ and two MRL $(50 \mu \mathrm{L})$ in a total volume of $500 \mu \mathrm{l}$ $2 \% \mathrm{MeCN}$. For milk, PPWS-milk was added to the dried extracts to obtain concentrations corresponding to $0.5 \mathrm{MRL}$ $(25 \mu \mathrm{L})$ and two MRL $(100 \mu \mathrm{l})$ in a total volume of $200 \mu \mathrm{l}$ $2 \% \mathrm{MeCN}$.

At the beginning of each series, a working standard containing the penicillin- $\mathrm{d}_{0}$-piperidines and the penicillin$\mathrm{d}_{10}$-piperidines was injected to check the performance of the instrument. 


\section{Validation}

The method for porcine muscle tissue was validated in a 5day experimental setup. On three separate occasions, using three different blank porcine muscle materials, samples were fortified with a mixture of penicillins (PWS-tissue) at three levels (0.5 MRL, one MRL and 1.5 MRL). Six replicates, at each of the three fortification levels, were analysed on each day. Accuracy, intra-day precision (repeatability), inter-day precision (within-lab reproducibility, muscle tissue only), recovery, linearity, $\mathrm{CC}_{\alpha}$ and $\mathrm{CC}_{\beta}$ were determined. Additionally (day 4), 20 blank samples were analysed to determine selectivity, specificity and limit of detection (LoD; the concentration at which the quantifier product ion has a signal to noise ratio of 3 ). The method for muscle tissue was tested (day 5) for ruggedness according to Youden [24]. Variables that were tested included the $\mathrm{pH}$ of the phosphate buffer, the piperidine derivatisation time, the heating temperature of the derivatised extract, the drying time of the SPE cartridge before elution of the purified extract and the composition of the elution solvent and the time lag before the dried sample was reconstituted. Porcine kidney tissue was additionally validated using six replicates, at each of the three fortification levels on one occasion.

The validation for milk was limited to seven replicate measurements at MRL on 1 day. Intra-day precision and accuracy at MRL level, linearity, specificity and selectivity were determined.

The validation for feedstuffs was carried out on seven separate occasions using multi-level standard addition. Of each of the 20 blank feed samples (representing feeding stuffs intended for poultry, porcine, bovine, ovine), 11 subsamples were processed. Two samples were not spiked with PWS-feed (blanks), six samples were fortified at one of the validation levels $\left(0.1,0.2,0.5 \mathrm{mg} \mathrm{kg}^{-1}\right)$ in duplicate and the remaining three samples were fortified at 1,2 and $5 \mathrm{mg} \mathrm{kg}^{-1}$, respectively. Each validation level was quantified by using the first three addition levels and applying linear regression of the least squares. The sum of the peak areas of the two product ions was used to calculate the response factor relative to the IS. Accuracy, intra-day precision, interday precision, linearity, $\mathrm{CC}_{\alpha}, \mathrm{CC}_{\beta}$, specificity, selectivity and stability of the extracts were determined.

\section{Results and discussion}

Synthesis of penicillin-piperidine derivatives

For the antibacterial activity of penicillins, an intact Blactam ring is essential. Acid- or base-catalysed hydrolysis of the B-lactam ring will result in inactive penicilloic acids and degradation products thereof [26-28]. Penicillins containing a primary amino group may also isomerise to (inactive) diketopiperazine derivatives [27, 28]. Other nucleophiles, such as alcohols and amines, can also react with the B-lactam ring, resulting in the formation of penicilloylic esters and (substituted) amides [29, 30]. In case ammonia or simple primary amines are used, the reaction is also called aminolysis. To our knowledge, the reaction of penicillins with secondary amines has not been studied in detail. We found that the reaction of a variety of penicillins with a concentrated solution of piperidine in water proceeded within minutes at room temperature. The synthesis of the derivatised penicillins does not require any special equipment. For the penicillins studied, a single compound was produced in high yield. In all cases, the corresponding piperidine derivative was formed by addition to the ß-lactam carbonyl group, followed by ring opening. In Fig. 2, the ${ }^{1} \mathrm{H}-\mathrm{NMR}$ spectrum of amoxicillin- $\mathrm{d}_{0^{-}}$ piperidine (AMX- $\left.\mathrm{d}_{0}-\mathrm{PIP}\right)$ is shown as an example. In AMX $\beta$-lactam protons, $\mathrm{H}_{5}$ and $\mathrm{H}_{6}$ resonate at 5.40 and $5.58 \mathrm{ppm}$, while in the ring-opened AMX- $\mathrm{d}_{0}$-PIP they have shifted to 4.85 and $4.92 \mathrm{ppm}$. The piperidine protons are found at $1.65 \mathrm{ppm}(6 \mathrm{H})$ and $2.96 \mathrm{ppm}(4 \mathrm{H})$.

It is possible to isolate the penicillin-piperidine derivatives by crystallisation, but in practise it is more convenient to prepare the standards in situ and store them at $-20{ }^{\circ} \mathrm{C}$ or lower, without further purification. It was verified by ${ }^{1} \mathrm{H}$ NMR that during the reaction no or little epimerisation at the 6 position occurs. However, during long-term storage, some epimerisation may occur in solution, even when the standards are kept at $-20{ }^{\circ} \mathrm{C}$. After 12 months at $-20{ }^{\circ} \mathrm{C}$, a stock solution of AMX- $\mathrm{d}_{0}$-PIP contained $15 \%$ of the $6-\alpha$ epimer. Therefore, it was decided to synthesise new standards every 12 months.

The MS/MS spectra of AMX- $\mathrm{d}_{0}$-PIP and AMX- $\mathrm{d}_{10}$-PIP are presented in Fig. 3. The addition of piperidine is evident from the mass increment of $85 \mathrm{Da}$ in the deprotonated molecular ion (M-H) ${ }^{-}$(AMX: $m / z$ 364). Two major fragments are formed upon collision-induced dissociation: $\mathrm{m} / \mathrm{z}$ 371 (loss of $m / z 78$ or $\mathrm{H}_{2} \mathrm{~S}+\mathrm{CO}_{2}$ ) and $\mathrm{m} / \mathrm{z} 277$ (loss of $\mathrm{m} / \mathrm{z}$ 172 , loss of $\mathrm{H}_{2} \mathrm{~S}+\mathrm{CO}_{2}+$ loss of phenol $\left.(\mathrm{m} / \mathrm{z} 94)\right)$. Both fragments still contain the piperidine ring. In the MS/MS spectrum of the corresponding $\mathrm{d}_{10}$-analogue, the expected mass shift of $10 \mathrm{Da}$ is seen for the $(\mathrm{M}-\mathrm{H})^{-}$and both fragments.

Method development

Penicillins do not only react quickly with piperidine but also with other primary (e.g., methylamine, aminoethanol) and secondary amines (diethyl amine, morpholine, piperazide). Piperidine was chosen as the derivatisation reagent of choice because a suitable deuterated analogue is 
<smiles></smiles>

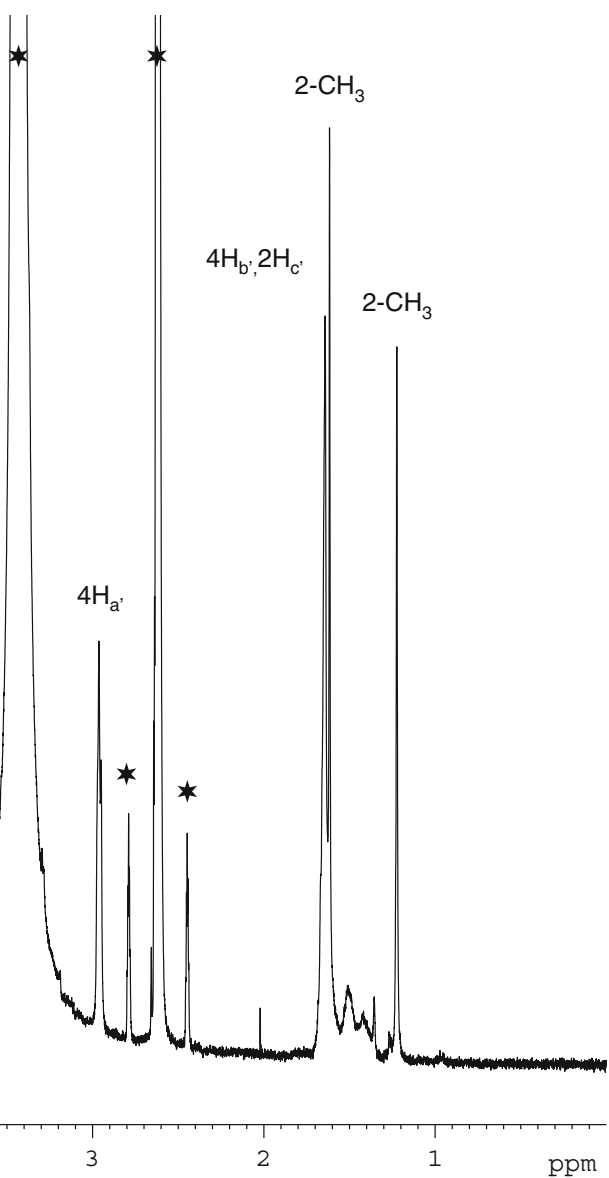

Fig. $2{ }^{1} \mathrm{H}$-NMR of amoxicillin- $\mathrm{d}_{0}$-piperidine, recorded in $\mathrm{CD}_{3} \mathrm{OD}$. Stars indicate solvent and residual water resonances

available and the derivatives produced exhibit favourable chromatographic behaviour. Amoxicillin is the most polar penicillin, eluting shortly after the void volume on a $\mathrm{C} 18$ HPLC column. AMX- $\mathrm{d}_{0}$-PIP exhibits increased retention, eluting at $4.4 \mathrm{~min}$ with the gradient used in this study (Fig. 4). The derivatised penicillins are most conveniently recorded in electrospray negative mode. For all compounds, loss of the $\mathrm{m} / \mathrm{z} 78$ fragment is the first or second most prominent fragmentation pathway. Next to the loss of the $\mathrm{m} / \mathrm{z} 78$ fragment, for each penicillin derivative, one structure-specific fragment has been included in the MRM method as well (Table 2).

It was verified that the derivatisation is specific for penicillins containing an intact $\beta$-lactam and that no reaction occurs with hydrolysed or degraded penicillins that potentially could interfere with the mass spectrometric analysis. Penicillins were degraded in solution by reaction with $0.1 \mathrm{~N}$ sodium hydroxide and with $0.1 \mathrm{~N}$ hydrochloric acid, until LC-MS/MS analysis indicated the complete conversion to hydrolysed or degraded products [26, 28]. Piperidine was added to the samples and subsequent LCMS/MS indicated no change in the composition of the samples, nor any formation of penicillin-piperidine deriv- atives from the hydrolysed or degraded penicillins. Hence, it can be concluded that the derivatisation is very specific for penicillin residues containing an intact B-lactam ring and that, in line with EU regulations, only the pharmacologically active residues are determined [4].

The $\mathrm{pH}$ of the extract during derivatisation was identified as a critical factor. In Fig. 5, the effect of $\mathrm{pH}$ on the derivatisation efficiency is shown. Piperidine was added in three different amounts to a solution of AMX in phosphate buffer $(100 \mathrm{mM})$ with a $\mathrm{pH}$ ranging from 3 to 9. By addition of piperidine, which acts as a base, the $\mathrm{pH}$ of the buffer solution is raised. Figure 5 shows that derivatisation is catalysed by high $\mathrm{pH}$ (11 or higher); at neutral or acidic $\mathrm{pH}$, the reaction proceeds very slowly and byproducts (due to hydrolysis) are produced. Therefore, an excess of piperidine is used to insure an alkaline $\mathrm{pH}$. However, prolonged exposure of the extracts to high $\mathrm{pH}$ may in turn lead to degradation of the matrix and this may affect sample cleanup. By adding phosphoric acid after 5 min of reaction, degradation of the matrix is minimised.

Although the use of deuterated internal standards facilitates the accurate quantification of penicillin residues in animal tissues and milk, the results for animal feed 


\section{Amoxicillin-d $d_{0}$-piperidine}

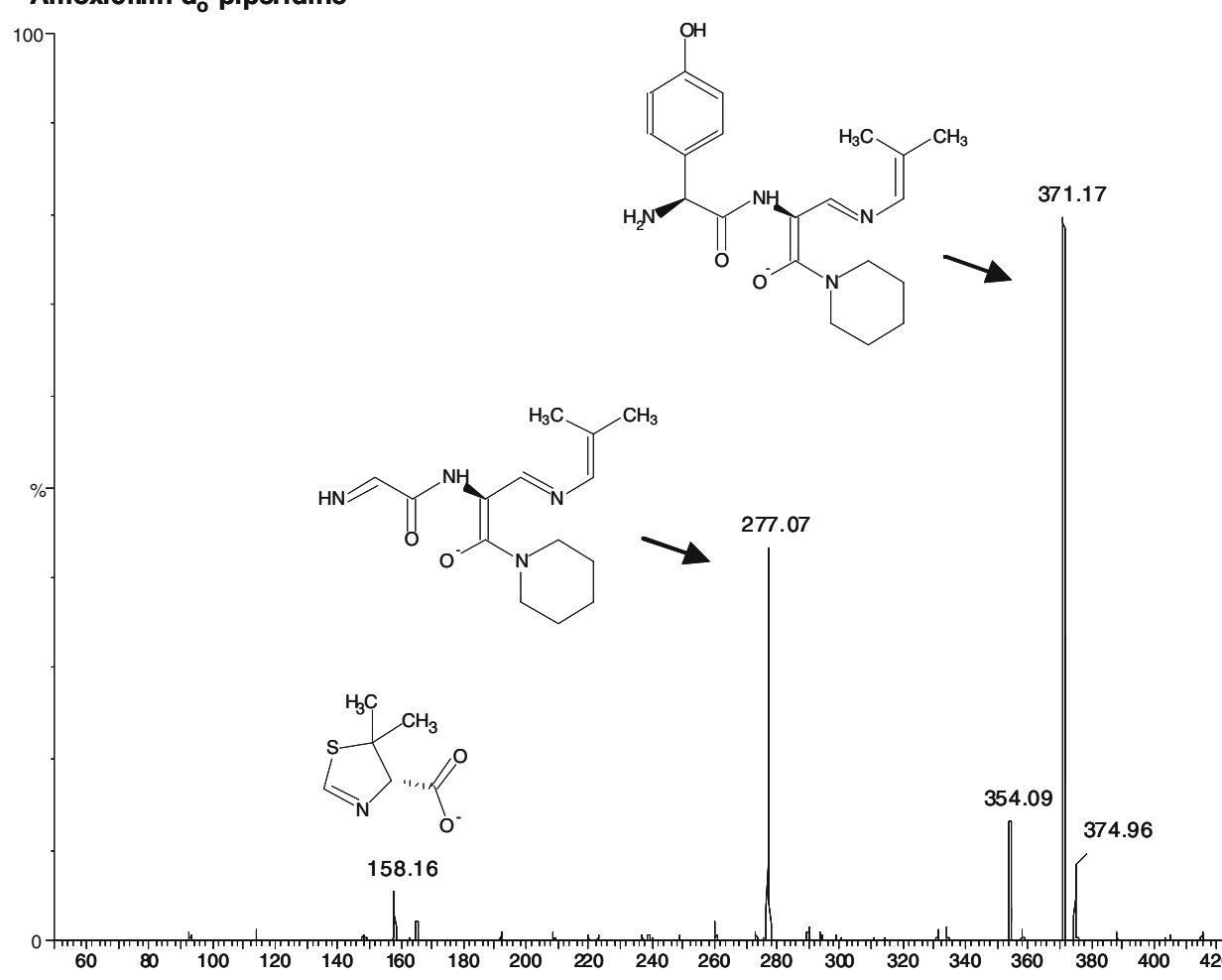

449.13

Daughters of $449 E S$ -<smiles>CC1(C)SC([C@H](NC(=O)[C@@H](N)c2ccc(O)cc2)C(=O)N2CCCCC2)N[C@H]1C(=O)[O-]</smiles>

Amoxicillin- $\mathrm{d}_{10}$-piperidine

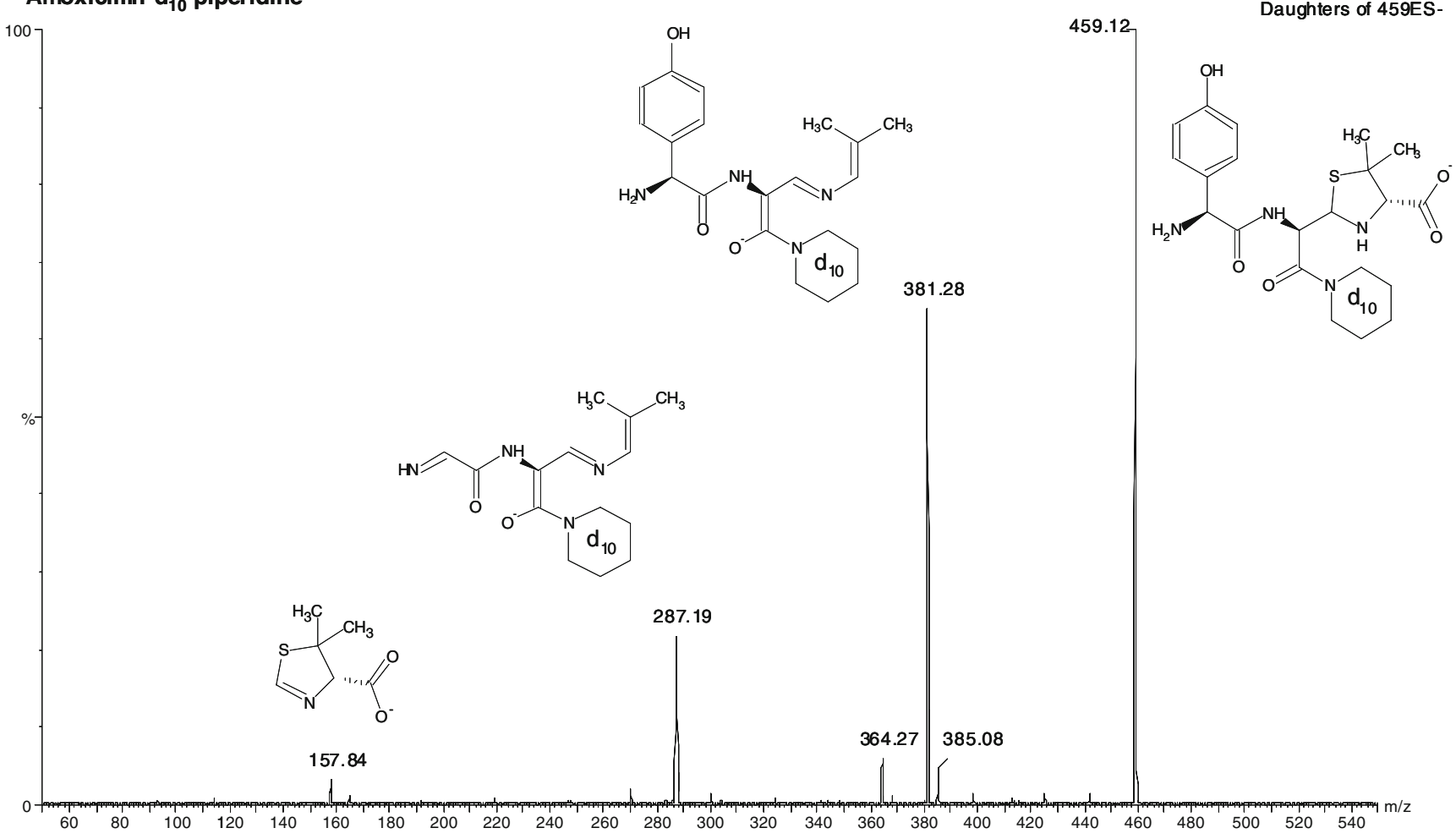

Fig. 3 MS/MS fragmentation spectra of amoxicillin- $\mathrm{d}_{0}$-piperidine $($ top $)$ and amoxicillin- $\mathrm{d}_{10}$-piperidine (below), recorded in electrospray negative mode at a collision energy of $15 \mathrm{eV}$ 


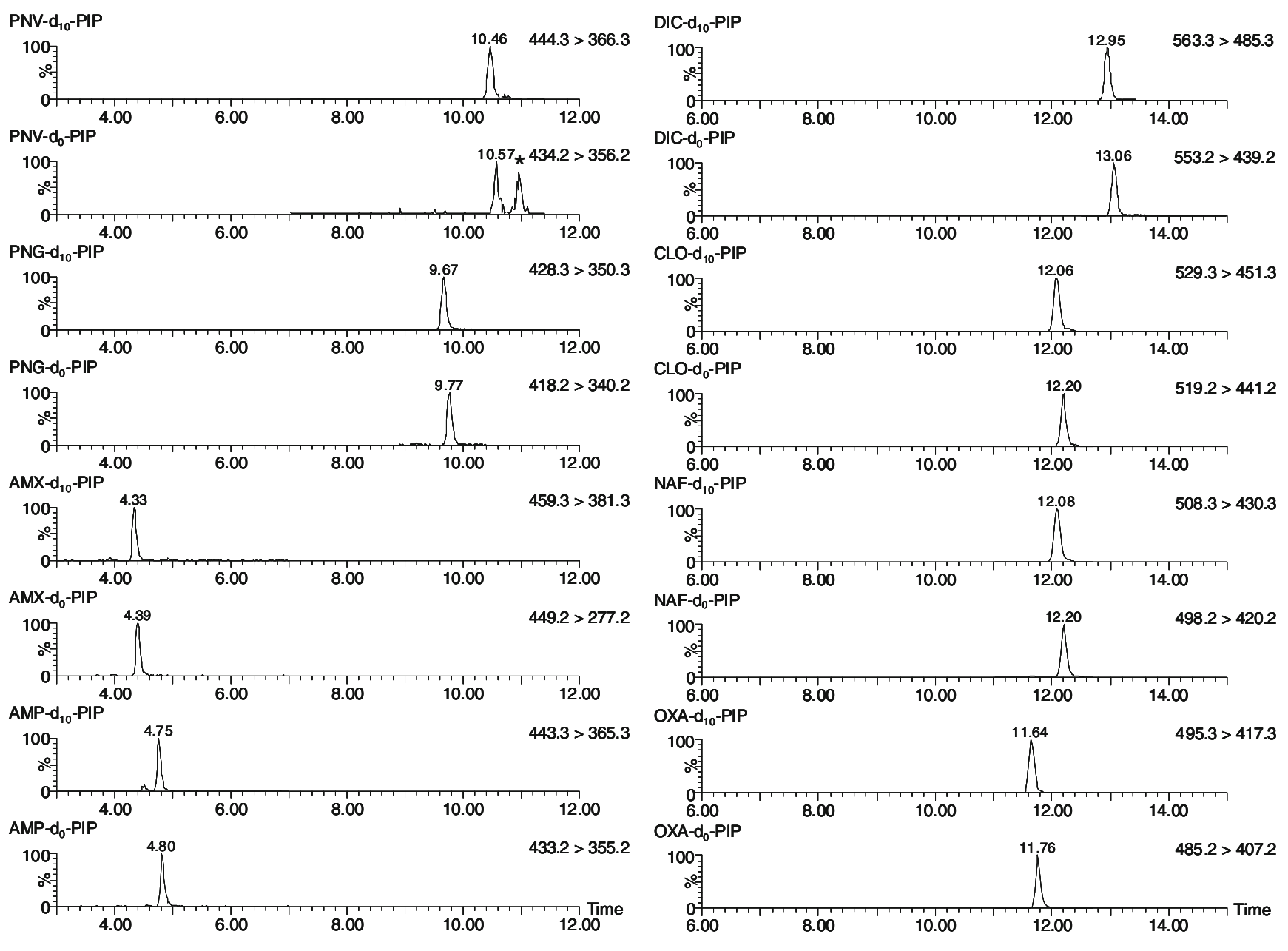

Fig. 4 LC-MS/MS chromatograms obtained for a blank porcine muscle sample spiked with a penicillin mix at MRL. For each penicillinpiperidine derivative, the quantifier trace is shown and the chromatogram for the corresponding IS transition. Stars indicate matrix interference

Fig. 5 Derivatisation of amoxicillin $\left(5 \mu \mathrm{g} \mathrm{ml}^{-1}\right)$ with piperidine as function of the $\mathrm{pH}$ of the solution $(100 \mathrm{mM}$ phosphate buffer, $\mathrm{pH} 3$ to 9) and the amount of piperidine added $(n=2 \pm \mathrm{SD})$. The effect of piperidine on the final $\mathrm{pH}$ of the solution is indicated

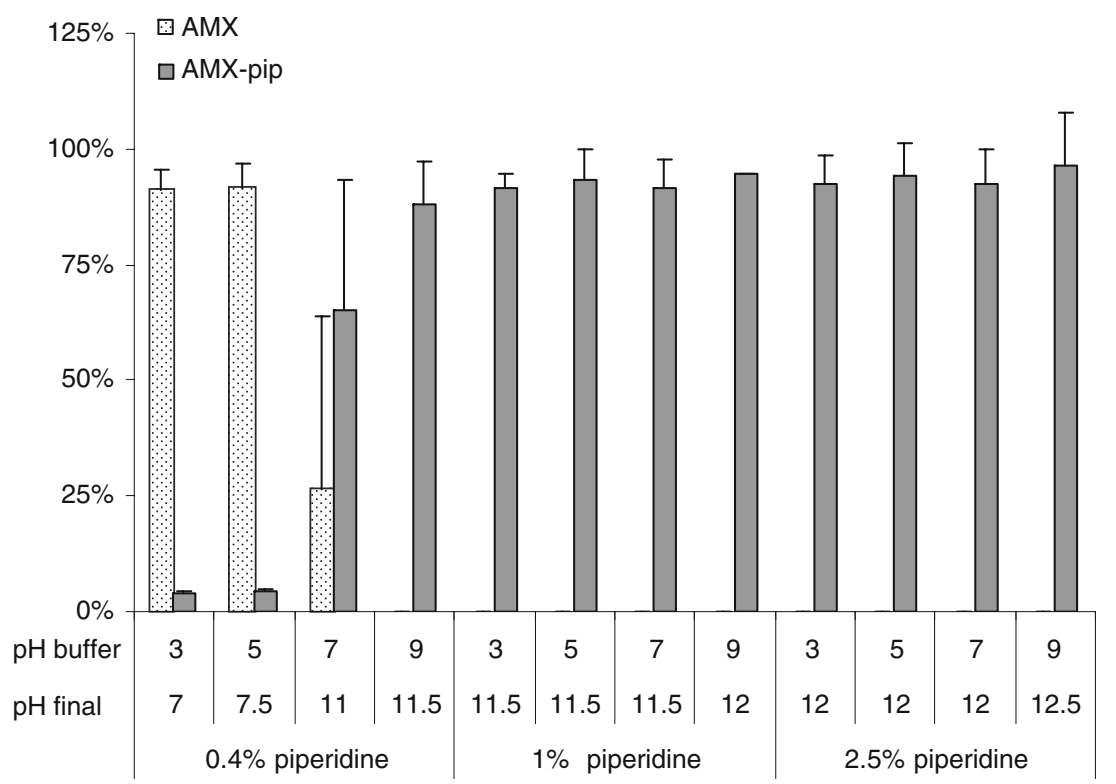




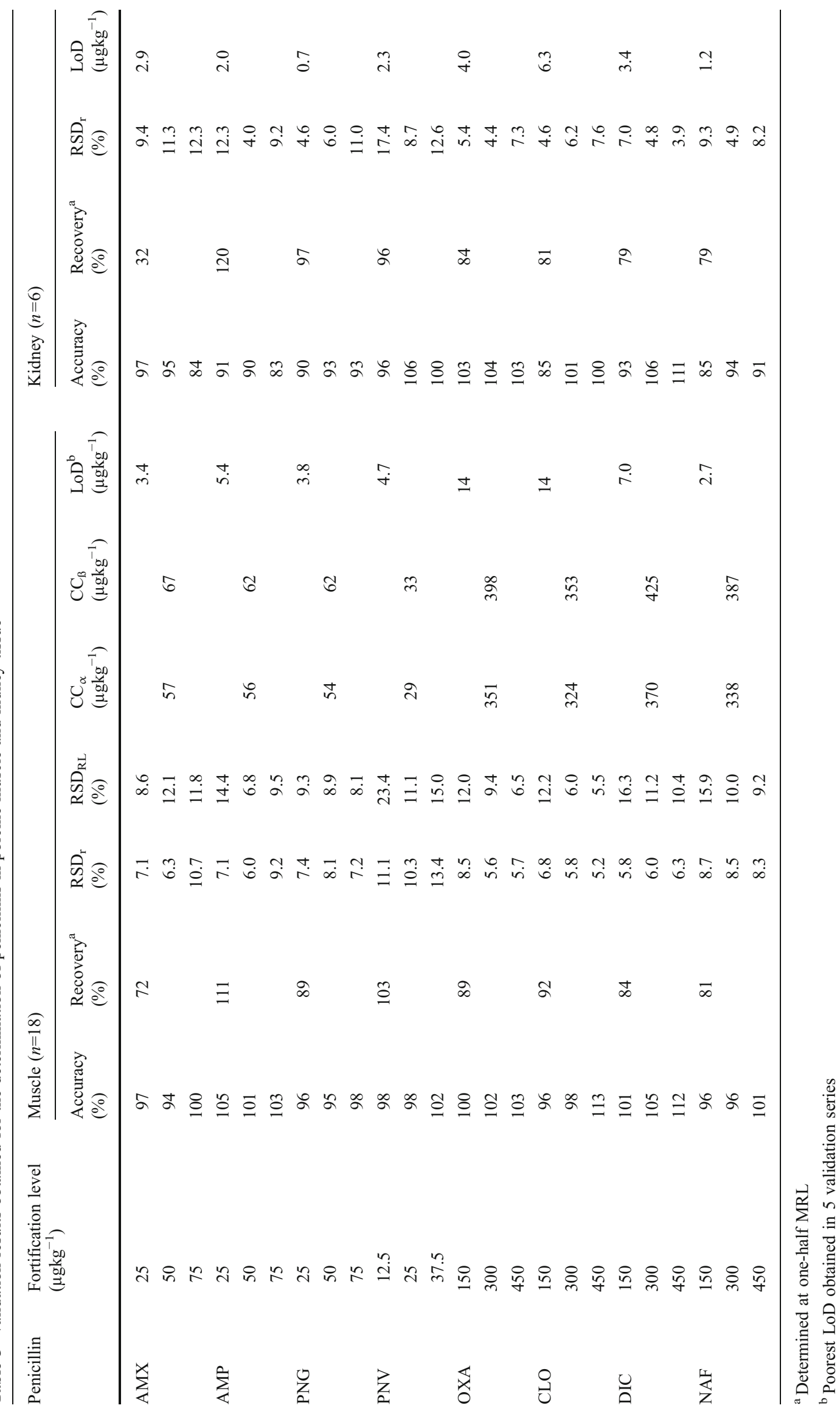


initially were less satisfactory, even with internal standard correction. This may be attributed to the large variability in composition, which can be found in feedstuffs. Raw materials and additives of feeds introduce many interfering components, such as oils, fats, proteins and salts, which can occur at very high levels. These constituents may influence the efficiency of sample preparation by causing differences in derivatisation and extraction efficiency and they may induce ion suppression effects during LC-MS/MS analysis. The internal standards are added to samples as derivatives and therefore only correct for ion suppression and variability in cleanup efficiency after derivatisation, but not for differences in derivatisation efficiency. Multi-level standard addition (MLSA) is therefore required for the analysis of animal feeds. MLSA eliminates differences in derivatisation efficiency, thereby improving accuracy and precision of the determination of penicillins in animal feed [31, 32]. Another possibility to reduce ion suppression effects may be dilution of the extract, as described by de Baere et al. [5], but this method was developed for medicated levels (200$500 \mathrm{mg} \mathrm{kg}^{-1}$ ). This is not an option when penicillins at a carryover level as low as $0.1 \mathrm{mg} \mathrm{kg}^{-1}$ have to be determined. Feeds with concentrations higher than $5 \mathrm{mg} \mathrm{kg}^{-1}$ need to be diluted to comply with the linear dynamic range of the MS detector, but it was not investigated if MLSA could be skipped for these diluted extracts.

\section{Validation}

The validation data for porcine muscle tissue were performed according to CD 2002/657/EC [24], and the results obtained are presented in Table 3. In Fig. 4, LC-MS/ MS chromatograms are shown for a processed blank muscle tissue sample spiked with penicillins at MRL. Accuracy in muscle tissue varied from $94 \%$ to $113 \%$ with an intra-day precision (relative standard deviation (RSD), $n=18$ ) between $5.2 \%$ and $13.4 \%$ and an inter-day precision $\left(\mathrm{RSD}_{\mathrm{RL}}, n=18\right)$ between $5.5 \%$ and $23 \%$. Requirements for accuracy (80-110\%), repeatability and within-laboratory reproducibility were met for all compounds at all levels with the exception of the accuracy for CLO (113\%, 1.5 MRL). Only a few multi-residue HPLC $[13,14]$ and LCMS methods [31] have been reported that include all penicillins described in this paper. These studies reported comparable results. Slightly higher variability was observed for PNV, which at least in part, may be caused by the lower fortification levels, compared to the other penicillins. The $\mathrm{CC}_{\alpha}$ and $\mathrm{CC}_{\beta}$ values that were obtained for all penicillins at MRL comply with the EU criteria and were comparable to those reported for bovine muscle tissue, even though only four replicates per level per day $(n=12)$ were used in that study [31]. The average overall recovery determined at 0.5 and two MRL was $70 \%$ for AMX and higher than $80 \%$ for the other penicillins. No significant differences in recovery were observed between both fortification levels. Linearity of the MMS curve (0.25-5 MRL) was 0.995 or higher on each of the five validation days. Only in two instances (PNV 0.992 and NAF 0.986 , both on day 4) was (slightly) lower linearity observed. For each penicillin, the estimated LoD is five times or more below the specific MRL.

The method was tested for ruggedness in tissue according to Youden. From the experiment, it was concluded that samples must be reconstituted immediately after drying. By analysing 20 different blank porcine tissues, the method was proven to be specific and selective. No interfering signals were observed in any of the blanks at the relevant retention times.

Kidney tissue was validated using a single-day experimental setup because of similarity in matrix (porcine tissue) and fortification levels. The validity of this approach was checked by preliminary experiments during method development. These tests indicated that the performance characteristics were likely to be in the same range as the determined parameters for muscle tissue. Accuracy in kidney tissue varied from $83 \%$ to $111 \%$ with an intra-day precision $\left(\mathrm{RSD}_{\mathrm{r}}, n=6\right)$ between $4.0 \%$ and $17.4 \%$ (Table 3 ). Average recovery in kidney tissue was higher than $80 \%$ with the exception of AMX (36\%). Lower-than-average recoveries for amoxicillin in kidney tissue were also observed by Becker et al. [31]. They attributed this to loss of retention on SPE by overload of matrix compounds from the extract. Lower recoveries for AMX have also been reported for other matrices such as wastewater and honey $[17,33]$. Although recovery for AMX in kidney tissue is significantly lower than in muscle tissue, the accuracies in combination with RSDs obtained indicate that the internal standard corrects adequately for the loss in recovery. No other significant differences were observed between kidney and muscle samples during this study. This is in accordance with the report of Verdon et al. [14], but Becker et al. deemed kidney to be a more difficult matrix [31].

Table 4 Single-day validation results obtained for penicillins in milk $(n=7)$ at MRL

\begin{tabular}{lccc}
\hline Penicillin & Fortification $\left(\mu \mathrm{gkg}^{-1}\right)$ & Accuracy $(\%)$ & RSD $_{\mathrm{r}}(\%)$ \\
\hline AMX & 4 & 90 & 8.4 \\
AMP & 4 & 87 & 4.9 \\
PNG & 4 & 102 & 8.8 \\
PNV & 4 & 99 & 17.5 \\
OXA & 30 & 96 & 6.8 \\
CLO & 30 & 103 & 8.0 \\
DIC & 30 & 94 & 8.8 \\
NAF & 30 & 98 & 6.6 \\
\hline
\end{tabular}




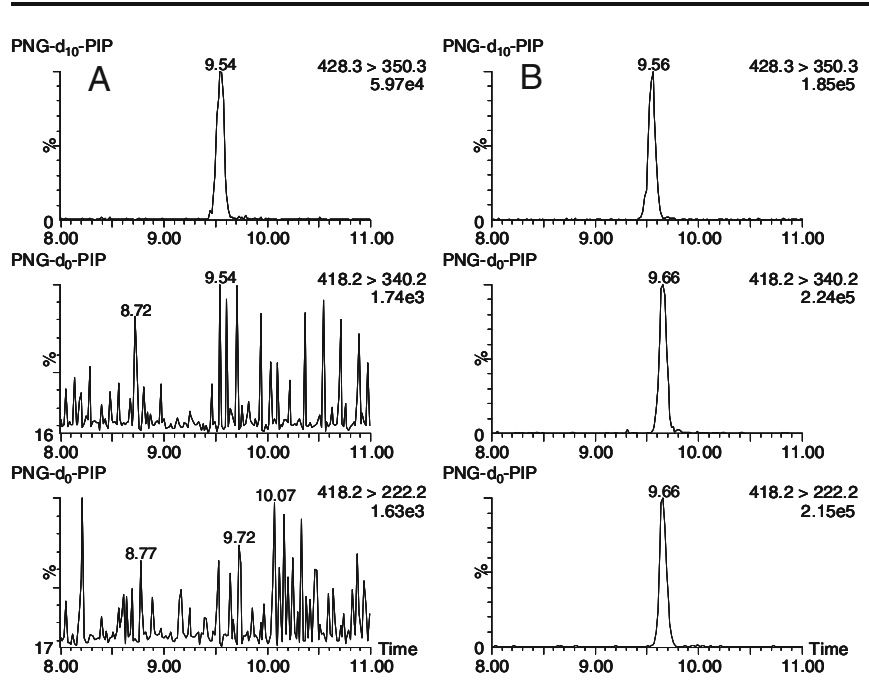

Fig. 6 Selected ion chromatograms for: a blank milk sample spiked with $4 \mu \mathrm{g} \mathrm{kg}^{-1}$ PNG-d ${ }_{10}$-PIP IS; b a (non-compliant) milk sample obtained from the National Residue Monitoring Program, containing

The method for muscle and kidney tissue was adapted for bovine milk. To accommodate for the (approximately tenfold) lower MRLs in milk, the protocol for porcine tissue was adjusted. A larger portion was processed, the

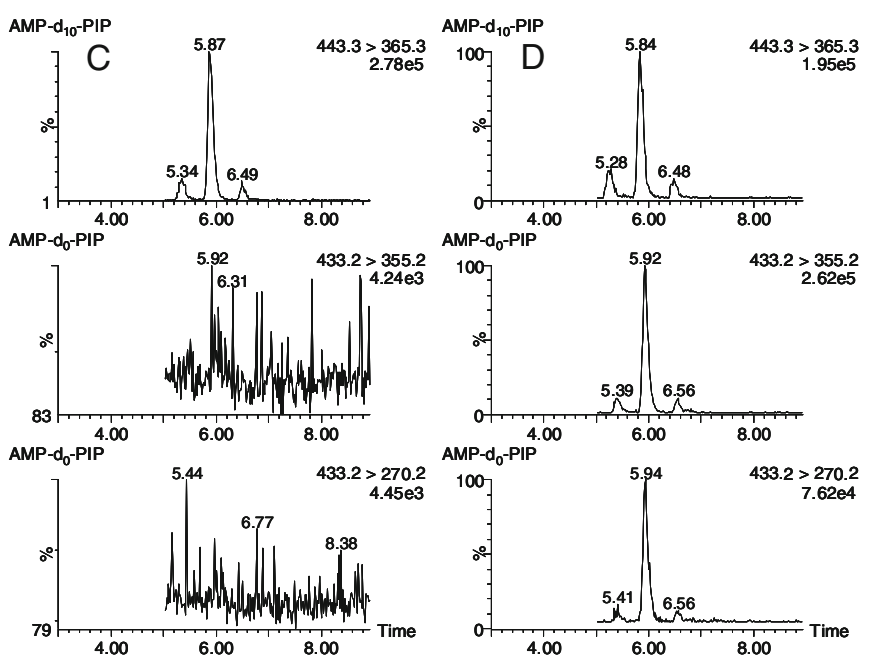

$5.2 \mu \mathrm{g} \mathrm{l}^{-1}$ PNG; $\mathbf{c}$ blank feed sample spiked with $10 \mathrm{mg} \mathrm{kg}^{-1} \mathrm{AMP}_{-\mathrm{d}_{10^{-}}}$ PIP IS; d A feed sample containing $45 \mathrm{mg} \mathrm{kg}^{-1}$ AMP (non-compliant). Of the feed extracts, $200 \mu \mathrm{l}$ was used for further SPE cleanup

final sample extract volume was reduced and the injection volume increased. In this way, the required detection limits could be achieved and confirmation of identity could be established for the penicillins (AMX, AMP, PNV, PNG)
Table 5 Validation results obtained for the analysis of penicillins in animal feed

\begin{tabular}{|c|c|c|c|c|c|c|}
\hline \multirow[t]{2}{*}{ Penicillin } & \multirow{2}{*}{$\begin{array}{l}\text { Fortification } \\
\left(\mathrm{mgkg}^{-1}\right)\end{array}$} & \multicolumn{5}{|c|}{ Animal feed $(n=18)$} \\
\hline & & Accuracy (\%) & $\mathrm{RSD}_{\mathrm{r}}(\%)$ & $\mathrm{RSD}_{\mathrm{RL}}(\%)$ & $\mathrm{CC}_{\alpha}\left(\mathrm{mgkg}^{-1}\right)$ & $\mathrm{CC}_{\beta}\left(\mathrm{mgkg}^{-1}\right)$ \\
\hline \multirow[t]{3}{*}{ AMX } & 0.1 & 107 & 29 & 32 & 0.15 & 0.20 \\
\hline & 0.2 & 88 & 23 & 25 & & \\
\hline & 0.5 & 92 & 15 & 16 & & \\
\hline \multirow[t]{3}{*}{ AMP } & 0.1 & 96 & 18 & 25 & 0.14 & 0.18 \\
\hline & 0.2 & 100 & 20 & 21 & & \\
\hline & 0.5 & 102 & 16 & 17 & & \\
\hline \multirow[t]{3}{*}{ PNG } & 0.1 & 102 & 11 & 14 & 0.12 & 0.14 \\
\hline & 0.2 & 106 & 13 & 13 & & \\
\hline & 0.5 & 112 & 24 & 25 & & \\
\hline \multirow[t]{3}{*}{$\mathrm{PNV}$} & 0.1 & 111 & 32 & 36 & 0.26 & 0.33 \\
\hline & 0.2 & 103 & 20 & 20 & & \\
\hline & 0.5 & 108 & 24 & 24 & & \\
\hline \multirow[t]{3}{*}{ OXA } & 0.1 & 100 & 11 & 11 & 0.12 & 0.13 \\
\hline & 0.2 & 99 & 14 & 18 & & \\
\hline & 0.5 & 112 & 24 & 24 & & \\
\hline \multirow[t]{3}{*}{ CLO } & 0.1 & 110 & 11 & 14 & 0.12 & 0.15 \\
\hline & 0.2 & 103 & 14 & 21 & & \\
\hline & 0.5 & 118 & 19 & 26 & & \\
\hline \multirow[t]{3}{*}{ DIC } & 0.1 & 106 & 14 & 18 & 0.13 & 0.16 \\
\hline & 0.2 & 102 & 13 & 13 & & \\
\hline & 0.5 & 116 & 21 & 21 & & \\
\hline \multirow[t]{3}{*}{ NAF } & 0.1 & 239 & 16 & 64 & 0.97 & 1.43 \\
\hline & 0.2 & 162 & 13 & 44 & & \\
\hline & 0.5 & 152 & 26 & 37 & & \\
\hline
\end{tabular}


with an MRL at $4 \mu \mathrm{g} \mathrm{kg}^{-1}$. To check the validity of the adjustments of the method made for bovine milk, the method was additionally validated at MRL using a singleday experimental setup. Accuracy in milk varied from $87 \%$ to $103 \%$ with an intra-day precision $\left(\mathrm{RSD}_{\mathrm{r}}, n=7\right)$ between $4.9 \%$ and $17.5 \%$ (Table 4 ). The accuracies obtained in milk were better than those reported by Kantiani [23]. On the other hand, intra-day precisions were slightly higher than those reported by Sørensen et al. [22] and Becker et al. [31]. Because the method for milk performed well at MRL, no further validation at other concentrations was carried out. LC-MS/MS traces of a compliant and a non-compliant milk sample (containing PNG above the MRL of $4 \mu \mathrm{g} \mathrm{kg}^{-1}$ ) from the National Residue Monitoring Program are shown in Fig. 6.

As there are no EU criteria established for the validation of veterinary drugs in animal feeds, the method for animal feed was validated according to CD 2002/657/EC for practical purposes. The validation was aimed at low carryover levels (100 to $500 \mu \mathrm{g} \mathrm{kg}^{-1}$ ). With the exception of NAF, accuracy in animal feed varied from $88 \%$ to $116 \%$, the intra-day precision $\left(\mathrm{RSD}_{\mathrm{r}}, n=18\right)$ between $11 \%$ and $32 \%$ and the inter-day precision $\left(\mathrm{RSD}_{\mathrm{RL}}, n=18\right)$ between $11 \%$ and $36 \%$ (Table 5). The accuracy for NAF was rather poor, resulting in an overestimation of the concentration (especially at the lowest fortification level) and consequently in a very high $\mathrm{CC}_{\alpha}$ and $\mathrm{CC}_{\beta}$. Inspection of the LC-MS/ MS data revealed that in some of the samples a matrix interference was co-eluting with NAF- $\mathrm{d}_{0}$-PIP. By analysing 20 different animal feeds, it was verified that for the other penicillins the method was specific and selective. No interfering signals were observed in any of the blanks at the relevant retention times. The linearity of the MLSA quantification (based on three additional fortification levels) ranged from 0.996 to 1.000 . LC-MS/MS traces of a blank animal feed sample and a non-compliant sample containing $45 \mathrm{mg} \mathrm{kg}^{-1}$ AMP are shown in Fig. 6. To our knowledge, a multi-residue method for penicillins at carryover level (0.1$2 \mathrm{mg} \mathrm{kg}^{-1}$ ) in feed has not been reported before. At medicated levels $\left(200-500 \mathrm{mg} \mathrm{kg}^{-1}\right)$, mostly single-residue methods have been described for AMX (which is the only penicillin registered for use in feed). The $\mathrm{RSD}_{\mathrm{r}}$ and $\mathrm{RSD}_{\mathrm{RL}}$ obtained by these methods are invariably lower than the ones reported in this study, but this is to be expected considering the much lower target levels in this study [5, 34, 35]. LoDs are much lower for the method reported in this paper.

The derivatisation with piperidine was also tested on the other important group of B-lactam antibiotics, the cephalosporins. Ideally, these compounds together with the penicillins and clavulanate should be incorporated into a general multi-residue ß-lactam method. Derivatisation experiments with clavulanate and several cephalosporins have thus far proved unsuccessful or produced the desired derivatives only with a low yield (results not shown). Apparently, cephalosporins do not react with piperidine in the same straightforward way as the penicillins.

\section{Conclusion}

The derivatisation of penicillins with piperidine and the incorporation of the corresponding deuterated penicillin piperidine internal standards not only improved the stability of the penicillins during sample workup but also improved accuracy, repeatability and within-lab reproducibility of the analytical method significantly. The developed multiresidue LC-MS/MS method for the analysis of penicillins in porcine tissue, milk and animal feed has been validated according to Commission Decision 2002/657/EC. Except for the quantitative determination of NAF in animal feed, the obtained validation parameters were all in accordance with the criteria mentioned in the decision. The in-house validation data collected showed that the method is robust and fit for purpose. This was also confirmed by the results of two recent proficiency tests on penicillin residues in milk and in porcine tissue. Excellent results were obtained for penicillin $G(Z$ score -0.26$)$ and cloxacillin $(Z$ score 0.21$)$ in milk [36] and for cloxacillin in muscle tissue $(Z$ score -0.06$)$ [37].

The method has been successfully implemented in the Dutch National Residue Control Program for the analysis of penicillins in kidney, muscle, milk and animal feed samples.

Open Access This article is distributed under the terms of the Creative Commons Attribution Noncommercial License which permits any noncommercial use, distribution, and reproduction in any medium, provided the original author(s) and source are credited.

\section{References}

1. Dayan AD (1993) Vet Microbiol 35:213-226

2. Dewdney JM, Maes L, Raynaud JP, Blanc F, Scheid JP, Jackson T, Lens S, Verschueren C (1991) Food Chem Toxicol 29:477-483

3. Doyle ME (2006) Veterinary drug residues in processed meatspotential health risk, FRI briefings. http://www.wisc.edu/fri/briefs/ FRIBrief VetDrgRes.pdf, March 2006

4. EC (2010) Council Regulation (EC) 37/2010/EC of 22 December 2009 on pharmacologically active substances and their classification regarding maximum residue limits in foodstuffs of animal origin (2010). Offic J Eur Comm L15:1-72

5. De Baere S, De Backer P (2007) Anal Chim Acta 586:319-325

6. EC (1990) Council Directive 90/167/EEC of 26 March 1990 laying down the conditions governing the preparation, placing on the market and use of medicated feeding stuffs in the Community, Council Directive 90/167/EEC (1990). Offic J Eur Comm L92:42-48

7. Riediker S, Stadler RH (2001) Anal Chem 73:1614-1621

8. Mastovska K, Lightfield AR (2008) J Chromatogr A 1202:118123 
9. Tyczkowska KL, Voyksner RD, Aronson AL (1992) J Chromatogr A 594:195-201

10. Riediker S, Rytz A, Stadler RH (2004) J Chromatogr A 1054:359-363

11. Verdon E, Fuselier R, Hurtaud-Pessel D, Couëdor P, Cadieu N, Laurentie M (2000) J Chromatogr A 882:135-143

12. Boison JO, Salisbury CDC, Chan W, MacNeil JD (1991) J AOAC Int 74:497-501

13. Sørensen LK, Snor LK, Elkær T, Hansen H (1999) J Chromatogr B Biomed Appl 734:307-318

14. Verdon E, Couëdor P (1999) J AOAC Int 82:1083-1095

15. Kantiani L, Farré M, Barceló D (2009) Trends Anal Chem 28:729-744

16. Schlösser J, Mehlich A, Ballwanz F, Petz M (1998) Fresenius' J Anal Chem 360:498-501

17. Wang J (2004) J AOAC Int 87:45-55

18. Goto T, Ito Y, Yamada S, Matsumoto H, Oka H (2005) J Chromatogr A 1100:193-199

19. Blanchflower WJ, Hewitt SA, Kennedy DG (1994) Analyst 1994:2595-2601

20. Daeseleire E, De Ruyck H, Van Renterghem R (2000) Rapid Commun Mass Spectrom 14:1404-1409

21. Fagerquist CK, Lightfield AR, Lehotay S (2005) Anal Chem 77:1473-1482

22. Sørensen LK, Rasmussen BM, Boison JO, Keng L (1997) J Chromatogr B 694:383-391

23. Kantiani L, Farré M, Sibum M, Postigo C, López de Alda MJ, Barceló D (2009) Anal Chem 81:4285-4295
24. EC (2002) Commission Decision 2002/657/EC of 12 August 2002 implementing Council Directive 96/23/EC concerning the performance of analytical methods and the interpretation of results. Offic J Eur Comm L221:8-36

25. Pikkemaat MG, Oostra-van Dijk S, Schouten J, Rapallini M, van Egmond HJ (2008) Food Control 19:781-789

26. Deshpande AD, Baheti KG, Chatterjee NR (2004) Curr Sci 87:1684-1695

27. Olsen MA, Cummings PG, Kennedy-Gabb S, Wagner BM, Nicol GR, Munson B (2000) Anal Chem 72:5070-5078

28. Nägele E, Moritz R (2005) J Am Soc Mass Spectrom 16:1670-1676

29. Llinás A, Donoso J, Vilanova B, Frau J, Muñoz F, Page MI (2000) J Chem Soc. Perkin Trans 2:1521-1525

30. Llinás A, Page MI (2004) Org Biomol Chem 2:651-654

31. Becker M, Zittlau E, Petz M (2004) Anal Chim Acta 520:19-32

32. Vincent U, Chedin M, Yasar S, von Holst C (2008) J Pharm Biomed Anal 47:750-757

33. Benito-Peña E, Partal-Rodera AI, León-González ME, MorenoBondi MC (2006) Anal Chim Acta 556:415-422

34. Benito-Peña E, Urraca JL, Moreno-Bondi MC (2009) J Pharm Biomed Anal 49:289-294

35. Gamba V, Dusi G (2003) Anal Chim Acta 483:69-72

36. Fuselier R, Juhel-Gaugain M, Gaudin V, Sanders P (2004) Proficiency testing for control of antibiotic residues in milk. AFSSA 2004/UQ

37. Berendsen BJA, Zuidema T (2007) Proficiency study for penicillins in porcine tissues, RIKILT report 2007.007. http:// library.wur.nl/way/bestanden/clc/1844975.pdf 